DOI: $10.29303 /$ jrpb.v8i1.169

ISSN 2301-8119, e-ISSN 2443-1354

Tersedia online di http://jrpb.unram.ac.id/

\title{
RANCANG BANGUN PROTOTIPE SALURAN IRIGASI SKALA LABORATORIUM
}

\author{
Design of Laboratory Scale Irrigation Channel Flow Prototype
}

\author{
Suhardi ${ }^{*}$ \\ Jurusan Teknik Pertanian, Fakultas Teknologi Pertanian, Universitas Jember \\ Jl. Kalimantan No. 37, Kampus Tegalboto, Jember 68121, Indonesia \\ Email $^{*}$ ): hardi.ftp@unej.ac.id \\ Diterima: Desember 2019 \\ Disetujui: Februari 2020
}

\begin{abstract}
Discharge measurements in irrigation canals can use a discharge measurement tool such as crested weirs, current meter, and buoy. Discharge measurement using crested weirs aim to efficiently manage irrigation water at the farm level. The type of crested weirs is width crested weirs and sharp-crested weirs. The sharp-crested weirs consist of triangles, trapezium, and rectangles. Based on the description, laboratory-scale irrigation channels prototype for simulation and discharge measurement experiments are equipped with rectangular sharpcrested weirs at the end of the channel. The aim of this study was the design of the prototype of the irrigation canal, functional test and the performance test of the irrigation channel flow prototype. The results showed that the prototype of the irrigation canal was functioning properly and could be used for discharge measurement experiments. The irrigation channel flow prototype performance test showed that the volumetric body was very accurate for measuring actual discharge with $R^{2}=0.999$. Meanwhile, the average calibration coefficient of discharge measurements using the Kinsvater-charter equation was 0.868 and the general equation was 0.983 .
\end{abstract}

Keywords: rectangular sharp-crested, discharge, calibration coefficient, irrigation channel flow prototype

\begin{abstract}
ABSTRAK
Pengukuran debit di saluran irigasi dapat dilakukan dengan alat ukur debit berupa bangunan ukur, current meter dan pelampung. Pengukuran debit mengunakan bangunan ukur ini bertujuan untuk efisiensi pengelolaan air irigasi di tingkat petani. Jenis bangunan ukur yang sering digunakan adalah bangunan ukur ambang lebar dan ambang tajam. Betuk bangunan ukur ambang tajam terdiri dari segitiga, trapesium dan segi empat. Berdasarkan uraian tersebut, prototipe saluran irigasi skala laboratorium dilengkapi dengan bangunan ukur ambang tajam segi empat di bagian ujung saluran untuk simulasi dan percobaan pengukuran debit. Tujuan dari penelitian ini adalah rancang bangun prototipe saluran irigasi, uji fungsional dan uji kinerja protipe saluran irigasi. Hasil penelitian menunjukkan bahwa prototipe saluran irigasi berfungsi dengan baik dan dapat digunakan untuk percobaan pengukuran debit. Uji kinerja prototipe saluran irigasi menunjukkan bahwa bak volumetrik sangat akurat untuk
\end{abstract}


pengukuran debit aktual dengan $\mathrm{R}^{2}=0,999$. Sementara itu rata-rata koefisien kalibrasi pengukuran debit menggunakan persamaan Kinsvater-carter adalah 0,868 dan persamaan umum adalah 0,983.

Kata kunci: bangunan ukur segi empat, debit, koefisien kalibrasi, prototipe saluran irigasi

\section{PENDAHULUAN}

Pengukuran debit secara tidak langsung pada saluran irigasi menggunakan bangunan ukur dengan tujuan untuk efisiensi pembagian air di tingkat petani dengan mempertimbangkan kebutuhan air tanaman yang harus diberikan. Bangunan ukur debit yang sering digunakan antara lain bangunan ukur ambang tajam segi empat dan bangunan ukur trapesium. Bangunan ukur tersebut biasanya dipasang pada saluran primer, saluran sekunder maupun saluran tersier. Pada umumnya, posisi bangunan ukur debit tegak lurus terhadap arah aliran (Al Shaikhli \& Kadhim, 2018).

Pengkuran debit saluran irigasi di laboratorium biasanya menggunakan prototipe saluran dengan dimensi saluran lebih kecil dari saluran sebenarnya. Oleh karena itu, rancang bangun prototipe saluran irigasi sangat diperlukan untuk memenuhi kebutuhan simulasi dan percobaan pengukuran debit di laboratorium. Struktur dan dimensi prototipe saluran irigasi skala laboratorium disesuaikan dengan ketersediaan ruangan. Dimensi prototipe saluran irigasi yang ditempatkan di dalam ruangan laboratorium berukuran lebih kecil apabila dibandingkan dengan ukuran prototipe yang ditempatkan di luar ruangan laboratorium. Prototipe saluran irigasi yang telah dikembangkan oleh Edijantno dkk., (2019) dilengkapi dengan bangunan ukur ambang tajam segi empat dan segi tiga Bangunan ukur jenis ini telah banyak digunakan pada saluran irigasi di lapangan.

Jenis bangunan ukur ambang tajam trapesium dan segitiga merupakan jenis bangunan ukur lainnya yang sering digunakan untuk pengukuran debit. Namun demikian, ketiga jenis bangunan ukur ini mempunyai fungsi yang berbeda. Bangunan ukur ambang tajam segi empat dan trapesium digunakan untuk mengukur debit aliran besar. Sementara bangunan ukur ambang tajam segitiga digunakan untuk mengukur debit aliran kecil dengan akurasi cukup tinggi (Sumirman \& Lasminto, 2013).

Masing-masing jenis bangunan ukur mempunyai persamaan matematik. Bangunan ukur ambang tajam segi empat sering menggunakan persamaan Rehbock, persamaan Kinsvater - Carter, dan persamaan Umum dengan persyaratan dan ketentuan yang berbeda. Ketiga persamaan matematik tersebut diperuntukan pada bangunan skala lapangan seperti yang tertuang dalam SNI 8137:2015. Oleh karena itu, uji kinerja prototipe saluran irigasi ini bersifat laboratorium sehingga prototipe bangunan ukur ini mempunyai perbedaan karakteristik fisik dengan bangunan yang sebenarnya di lapangan (Pudyono, 2010).

Tujuan dari penelitian ini adalah (1) merancang prototipe saluran irigasi untuk pengukuran debit skala laboratorium; (2) melakukan uji fungsional dan uji kinerja prototipe saluran irigasi dalam pengukuran debit aktual dan pengukuran debit menggunakan bangunan ukur ambang tajam segi empat dengan persamaan Kinsvater Carter, dan persamaan umum. Uji kinerja bangunan ukur perlu dilakukan untuk memastikan bangunan ukur dalam kondisi baik dan akurat dalam pengukuran debit, sehingga efisiensi pembagian air pada lahan pertanian dapat tercapai sesuai kebutuhan air tanaman. Manfaat yang diperoleh dari penelitian adalah tersedianya (1) prototipe saluran irigasi yang dapat digunakan untuk percobaan pengukuran debit skala laboratorium; (2) pengetahuan ilmiah tentang pengukuran debit teoritis menggunakan bangunan ukur dan pengukuran debit aktual. 


\section{METODE PENELITIAN}

\section{Waktu dan Lokasi Penelitian}

Penelitian ini dilaksanakan bulan Mei 2019 sampai dengan Oktober 2019. Penelitian ini bertempat di Laboratorium Teknik Pengendalian dan Konservasi Lingkungan Jurusan Teknik Pertanian Fakultas Teknologi Pertanian Universitas Jember.

\section{Alat dan Bahan Penelitian}

Penelitian ini menggunakan peralatan antara lain stopwatch, penggaris, gergaji besi, jangka sorong, prototipe bangunan ukur segi empat, dan gelas ukur kapasitas 1 liter. Sementara bahan yang digunakan adalah lem super sealant, aklirik, besi siku berlubang, pipa pvc, dan selang plastik.

\section{Tahapan Penelitian}

Penelitian ini dilakukan dengan beberapa tahapan seperti tampak pada diagam alir penelitian pada Gambar 1 .

\section{Desain Prototipe Saluran irigasi}

Keberhasilan kegiatan rancang bangun peralatan dipengaruhi oleh hasil analisis perancangan itu sendiri. Analisis perancangan sangat membantu dalam penentukan kebutuhan komponen dari peralatan tersebut. Secara umum analisis perancangan terdiri atas analisis fungsional dan analisis strutural. Analisis fungsional berfungsi untuk menghitung kebutuhan dari komponen peralatan tersebut. Sementara itu analisis struktural berfungsi untuk menentukan bentuk struktur yang sesuai dengan kebutuhan. (Susilo, 2009 dalam Suhardi, 2015).

Dalam perancangan suatu jaringan irigasi perlu diperhatikan standar dan

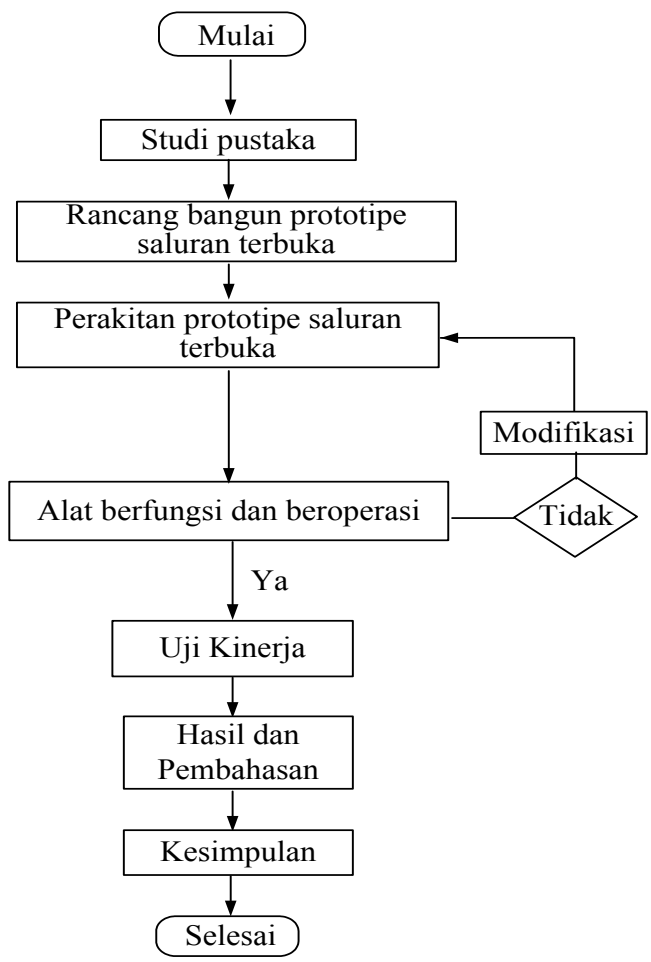

Gambar 1. Diagram alir penelitian

kriteria perencanaan, mengingat data-data dasar dan standar perhitungan jaringan
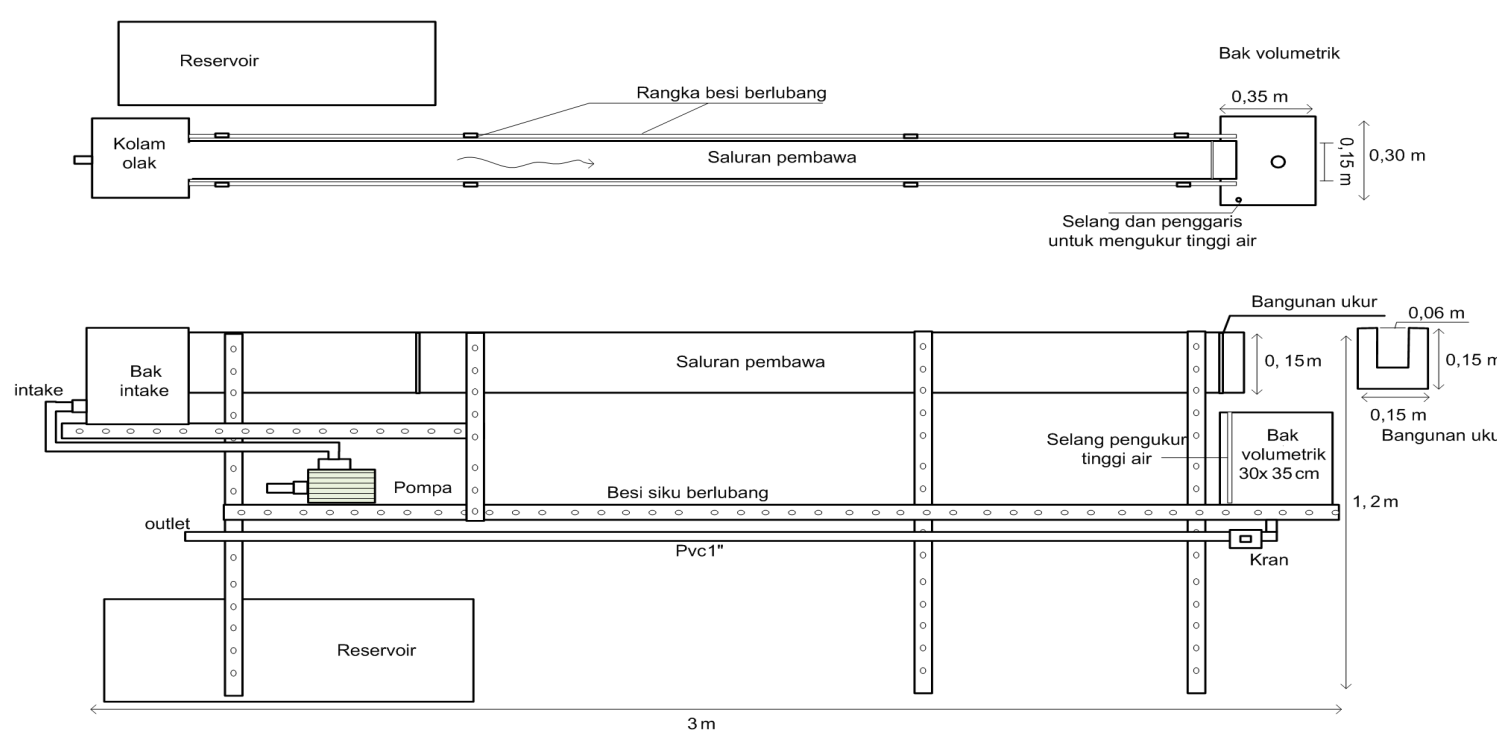

Gambar 2. Struktur prototipe saluran irigasi 
irigasi diberikan dalam kriteria perencanaan ini (Direktorat Jenderal Pengairan dan Pekerjaan Umum, 1986). Penetapan kriteria perencanaan juga berfungsi untuk menentukan parameter-parameter yang diharapkan pada prototipe yang akan dibuat (Yusuf, dkk., 2017).

Struktur prototipe saluran irigasi skala laboratorium hasil desain tampak pada Gambar 2. Kolam olak berukuran $30 \mathrm{~cm} \mathrm{x}$ $25 \mathrm{~cm}$ diharapkan mampu menampung olakan air yang terjadi akibat gesekan atau benturan diantara molekul-molekul air. Saluran pembawa dengan dimensi $15 \mathrm{~cm} \mathrm{x}$ $15 \mathrm{~cm}$ didasarkan pada pertimbangan bahwa debit yang dialirkan ke saluran relatif kecil sehingan dengan dimensi tersebut tidak terjadi luapan air. Sementara itu, panjang saluran pembawa dirancang $3 \mathrm{~m}$ dengan harapan aliran air pada saluran tidak bergolak karena jarak antara intake dan bangunan ukur debit cukup panjang. Pertimbangan lainnya adalah saluran pembawa dengan panjang $3 \mathrm{~m}$ ini diharapkan mampu mengalirkan air secara perlahan-lahan ke bagian hilir dan tercapai keseimbangan antara tahanan dan gaya berat sehingga pada kondisi ini pula aliran seragam terjadi. Dengan demikian pembacaan tinggi air di atas mercu pada papan duga menjadi stabil.

\section{Uji Fungsional}

Uji fungsional dilakukan setelah peralatan selesai dirakit. Uji fungsional dilakukan dengan cara pengamatan masingmasing komponen. (Yusuf, dkk., 2017). Pengamatan fungsional pada komponen prototipe saluran ini meliputi pengamatan pada kolam olak, saluran pembawa dan bangunan ukur. Kolam olak berfungsi mereduksi energi aliran. Dengan demikian, kolam olak dinyatakan berfungsi apabila energi aliran yang terjadi di kolam olak tereduksi sedemikian rupa sehingga aliran air yang masuk ke saluran tidak menimbulkan gerusan pada dasar dan dinding saluran (Ulfiana, 2018). Saluran pembawa berfungsi sebagai saluran yang membawa air dari sumbernya ke lahan pertanian. Oleh karena itu, standar saluran pembawa ini tidak diperbolehkan adanya kebocoran agar tidak terjadi kehilangan air yang berdampak pada kekurangan air di lahan pertanian (Sisiwoyo, dkk., 2017). Di samping itu, standar saluran pembawa tidak diperbolehkan adanya endapan pada saluran (Direktorat Jenderal Sumber Daya Air, 2013). Endapatan yang terjadi pada saluran pembawa akan bedampak pada meluapnya air tanpa terkontrol (Susetyaningsih dan Permana, 2016). Sementara itu, bangunan ukur debit berfungsi untuk mengukur debit di saluran terbuka. Aliran yang terbentuk pada bangunan ukur ini harus terkontraksi penuh dengan aerasi sempurna sehingga aliran tenang dan tidak terpengaruh oleh kondisi di udik dan dasar saluran. Dengan demikian pengukuran debit menjadi akurat (Badan Standardisasi Nasional, 2015).

\section{Uji Kinerja}

\section{Perhitungan Debit}

Uji kinerja terhadap prototipe saluran irigasi dilakukan dengan menghitung debit aktual dan debit teoritis. Debit aktual dilakukan dengan mengukur volume yang tertampung dalam bak volumetrik pada kurun waktu tertentu. Sementara debit teoritis dihitung menggunakan persamaan bangunan ukur ambang tajam segi empat.

Pengukuran debit aktual dilakukan dengan menampung dan mengukur volume air yang melewati mercu, kemudian mencatat waktu yang diperlukan untuk menampung air tersebut (Waspodo, 2017). Debit aktual dapat dihitung dengan Persamaan 1.

$Q=\frac{V}{T}$

Dimana Q adalah debit aktual ( $\mathrm{m}^{3} /$ detik), V adalah volume air tertampung $\left(\mathrm{m}^{3}\right)$, dan $\mathrm{T}$ adalah waktu yang diperlukan untuk menampung air (detik).

Sementara itu, pengukuran debit teoritis menggunakan persamaan Kinsvater - Carter dan persamaan umum. Kedua persamaan ini digunakan untuk mengukur debit yang melalui bangunan ukur ambang 
tajam segi empat. Oleh karena itu, dimensi saluran pembawa, dimensi bangunan ukur, dan tinggi muka air di atas mercu menjadi parameter dalam perhitungan debit teoritis. Dimensi prototipe bagunan ukur meliputi lebar ambang tajam segi empat dan tinggi mercu diatas dasar saluran. Sementara itu, jarak antara tepi dinding saluran pembawa merupakan lebar saluran seperti tampak pada Gambar 3.

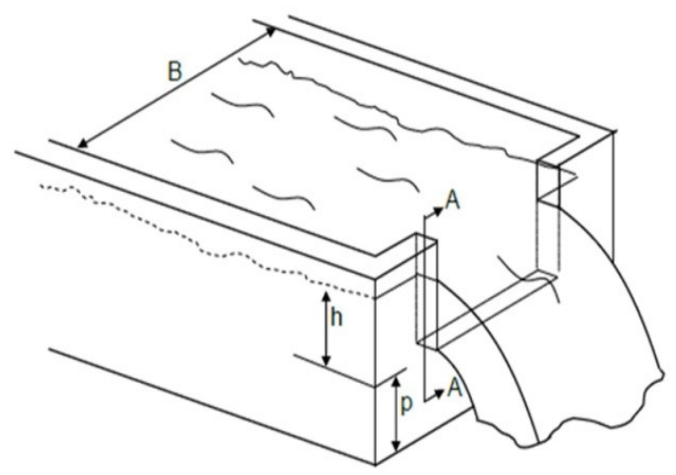

Gambar 3. Profil saluran dan bangunan ukur segi empat (Sumber: SNI 8137:2015)

Keterangan: $\mathrm{B}=$ lebar saluran pembawa, $\mathrm{p}=$ tinggi mercu dari dasar saluran, $\mathrm{h}=$ tinggi air dari mercu

Debit teoritis menggunakan persamaan Kinsvater-Carter dapat dihitung (Badan Standardisasi Nasional, 2015) seperti ditunjukkan oleh Persamaan 2.

$Q=\left[\frac{2}{3}\right] \sqrt{2 g} \cdot C_{d} \cdot b_{a} \cdot\left(H_{e f}\right)^{3 / 2}$

$\mathrm{Q}$ adalah debit $\left(\mathrm{m}^{3} /\right.$ detik$), \mathrm{g}$ percepatan gravitasi $\left(\mathrm{m} / \mathrm{det}^{2}\right)$, dan $\mathrm{H}_{\mathrm{ef}}$ adalah tinggi muka air efektif $(\mathrm{m})$, ba adalah panjang bentang mercu ambang efektif $(\mathrm{m})$ dan $\mathrm{Cd}$ adalah koefisien debit. $\mathrm{H}_{\mathrm{ef}}$ dapat dihitung dengan persaman 3 .

$\mathrm{Hef}=\mathrm{h}+\delta \mathrm{H}$

Dimana $\mathrm{h}$ merupakan tinggi air di atas mercu diukur menggunakan alat papan duga yang ditempatkan pada posisi $4 \mathrm{~h}_{\text {maks }}$ sampai dengan $5 h_{\text {maks }}$ di hulu bangunan ukur seperti tampak pada Gambar 4. $\delta \mathrm{H}$ adalah kondisi kekentalan fluida dan tegangan permukaan. Pada suhu air normal, $4^{\circ} \mathrm{C}$ sampai dengan $20^{\circ} \mathrm{C}, \delta \mathrm{H}$ sebesar $0,001 \mathrm{~m}$. Sementara itu ba dapat dihitung dengan Persamaan 4.

$\mathrm{ba}=\mathrm{b}+\delta \mathrm{b}$

Dimana $b$ adalah faktor koreksi yang merupakan fungsi $\frac{b}{B}$, untuk kondisi suhu air normal dan harga $\delta b$ dapat ditentukan berdasarkan Gambar 5.

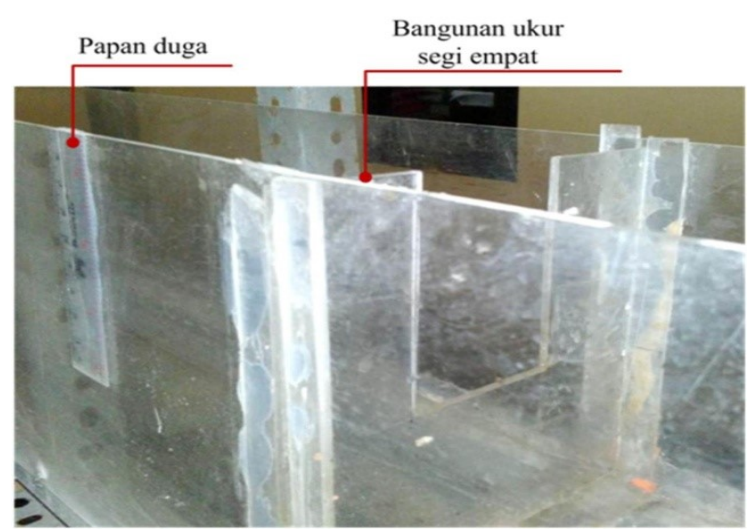

Gambar 4. Pengukuran tinggi air di atas mercu menggunakan papan duga

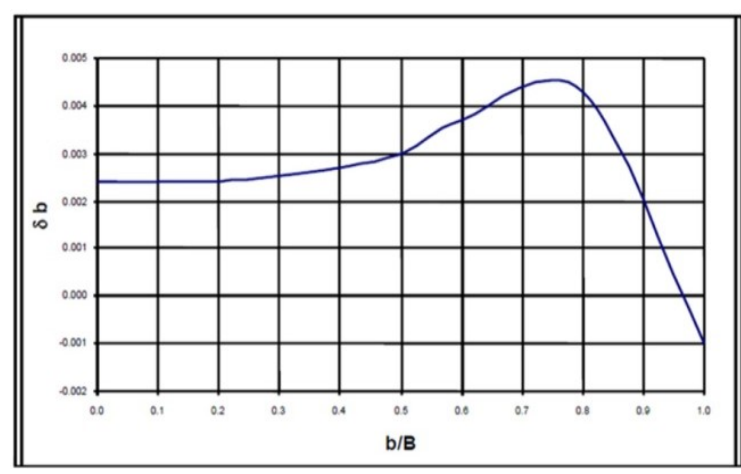

Gambar 5. Penentuan harga $\delta b$

(Sumber: SNI 8137, 2015)

Sementara itu, nilai koefisien debit, Cd dapat ditentukan berdasarkan harga $\frac{b}{B}$, seperti ditunjukkan pada Tabel 1.

Tabel 1. Penentuan harga Cd (Bagus, dkk., 2018)

\begin{tabular}{cc}
\hline $\mathrm{b} / \mathrm{B}$ & $\mathrm{Cd}$ \\
\hline 1,0 & $0,602+0,075 \mathrm{~h} / \mathrm{p}$ \\
0,9 & $0,599+0,064 \mathrm{~h} / \mathrm{p}$ \\
0,8 & $0,597+0,045 \mathrm{~h} / \mathrm{p}$ \\
0,7 & $0,595+0,030 \mathrm{~h} / \mathrm{p}$ \\
0,6 & $0,593+0,018 \mathrm{~h} / \mathrm{p}$ \\
0,5 & $0,592+0,011 \mathrm{~h} / \mathrm{p}$ \\
0,4 & $0,591+0,0058 \mathrm{~h} / \mathrm{p}$ \\
\hline
\end{tabular}




\begin{tabular}{cc}
\hline 0,3 & $0,590+0,002 \mathrm{~h} / \mathrm{p}$ \\
0,2 & $0,589+0,0018 \mathrm{~h} / \mathrm{p}$ \\
\hline
\end{tabular}

Perhitungan debit teoritis ambang tajam segi empat dapat juga dihitung menggunakan Persamaan 5 (Anggrahini, 2005).

$Q=1,71 m \cdot b \cdot h^{3 / 2}$

Dimana $\mathrm{Q}$ adalah debit $\left(\mathrm{m}^{3} /\right.$ detik $), \mathrm{m}$ koefisien debit $(0,9-1,30)$, dan $h$ adalah tinggi muka air (m), b adalah lebar mercu (m).

\section{Kalibrasi debit}

Kalibrasi debit dilakukan untuk menyesuaikan antara debit teoritis dan debit aktual. Perbedaan debit aktual dan debit teoritis ini sering terjadi dalam percobaan pengukuran debit dengan bangunan ukur. Oleh karena itu perlu dilakukan perhitungan koefisien kalibrasi menggunakan Persamaan 6 berikut (Hidayah \& Dermawan, 2015).

$K=\frac{Q a c t}{Q t}$

Dimana K adalah koefisien kalibrasi, Qact adalah debit aktual, dan Qt debit hasil perhitungan menggunakan persamaan bangunan ukur segi empat.

\section{Validasi Perhitungan Debit dan Kalibrasi Bangunan Ukur menggunakan Model Jaringan Saraf Tiruan (JST)}

Debit dan koefisien kalibrasi bangunan ukur hasil persamaan Kinsvatercarter dan persamaan umum divalidasi menggunakan model Jaringan Saraf Tiruan (JST). Pada umumnya arsitektur JST terdiri dari 3 layer: (1) input layer; (2) hidden layer; (3) output layer (Elsafi, 2014). Data input adalah debit aktual, sementara data target adalah debit teoritis persamaan Kinsvatercarter dan persamaan Umum. Pembagian komposisi data model JST terdiri training $50 \%$, validation $25 \%$, dan testing $25 \%$. Arsitektur JST seperti tampak pada Gambar 6.

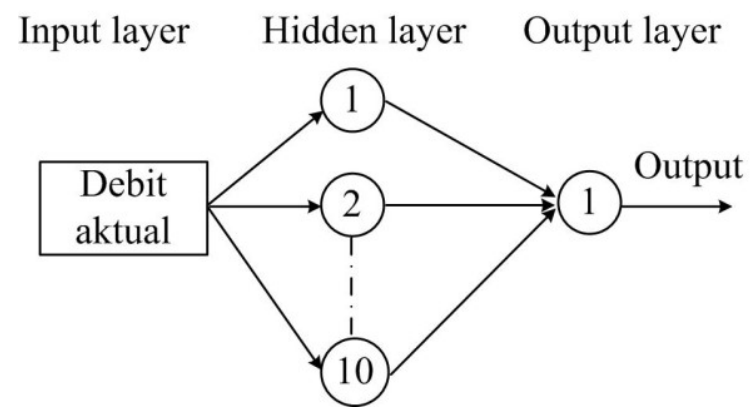

Gambar 6. Arsitektur JST

\section{HASIL DAN PEMBAHASAN}

\section{Perancangan dan Perakitan}

Kegiatan perancangan dan perakitan ini dilakukan secara bertahap antara lain sebagai berikut:

1. Perancangan prototipe saluran irigasi Pada tahap ini penentuan struktur dan pemilihan bahan menjadi salah satu pertimbangan agar pekerjaan pemotongan dan perakitan mudah dilakukan. Pertimbangan lainnya adalah harga bahan dan ketesediaan bahan di pasaran atau toko. Berdasarkan pertimbangan tersebut, bahan yang dipakai adalah: (a) besi siku berlubang yang berfungsi sebagai rangka struktur prototipe saluran irigasi; (b) aklirik sebagai bahan dari stuktur saluran irigasi yang terdiri dari kolam olak, saluran pembawa, bangunan ukur, dan bak volumetrik; dan (c) pompa air sebagai tenaga penggerak aliran air.

2. Perakitan bahan

Perakitan bahan harus memperhatikan ukuran masing-masing bagian struktur saluran irigasi sehingga proses perakitan sesuai jadwal yang telah ditentukan. Struktur prototipe saluran irigasi seperti tampak pada Gambar 7. 


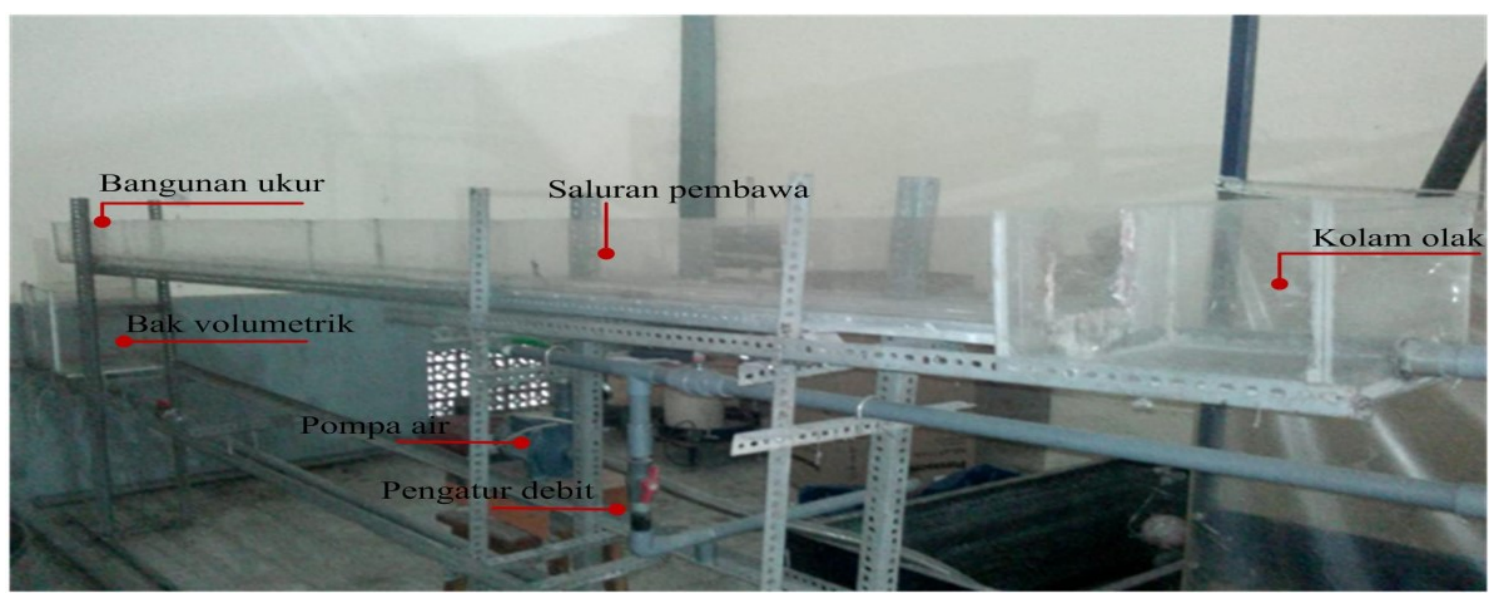

Gambar 7. Prototipe saluran irigasi skala laboratorium

\section{Uji Fungsi}

Uji fungsi ini dilakukan dengan cara simulasi untuk memastikan bahwa bagianbagian prototipe saluran terbuka berfungsi dengan baik. Bagian-bagian tersebut antara lain: (a) kolam olak; (b) saluran pembawa; (c) bangunan ukur; dan (d) bak volumetrik seperti tampak pada Gambar 7. Uji fungsi pada kolam olak, saluran pembawa dan bangunan ukur, serta bak volumetrik diuraikan sebagai berikut:

1. Kolam olak berfungsi meredam energi aliran air dari pompa sehingga aliran air tidak bergolak. Berdasarkan hasil pengamatan dapat dikemukakan bahwa pada tinggi air di atas mercu $1,7 \mathrm{~cm}$ atau debit persamaan umum 0,205 liter/detik menunjukkan bahwa kolam olak berfungsi sempurna. Hal ini ditunjukkan bahwa aliran seragam terjadi pada saluran di hilir atau dekat kolam olak. Namun pada tinggi air diatas mercu 1,8-2,1 cm atau kisaran debit 0,223 - 0,281 liter/detik terdapat aliran sedikit bergelombang pada saluran di hilir atau dekat kolam olak yang disebut juga zona transisi. Dengan demikian dapat dikatakan bahwa kolam olak berfungsi dengan baik, dimana kecepatan aliran air yang masuk ke saluran tereduksi sehingga pada kondisi ini tidak tejadi gerusan pada dasar dan dinding saluran.

2. Saluran pembawa berfungsi untuk mendistribuskan air dari pompa air menuju outlet. Pada saluran pembawa ini dilakukan pengamatan terhadap tingkat kebocoran dan kondisi aliran. Hasil pengamatan menunjukkan bahwa saluran pembawa tidak terjadi kebocoran. Sementara itu, kondisi aliran pada masing-masing debit dapat diuraikan bahwa pada tinggi air di atas mercu $1,7 \mathrm{~cm}$ atau debit persamaan umum 0,205 liter/detik menunjukkan aliran air seragam mulai dari hulu sampai hilir. Namun pada tinggi air di atas mercu 1,8 $2,1 \mathrm{~cm}$ atau kisaran debit 0,223-0,281 liter/detik kondisi aliran seragam tetapi sedikit bergelombang pada bagian hulu saluran atau zona transisi. Dengan demikian dapat dikemukakan bahwa saluran pembawa berfungsi dengan baik dan kondisi tunak tercapai pada debit 0,205 liter/detik.

3. Bangunan ukur yang terpasang pada ujung saluran pembawa berfungsi mengukur debit air yang melewati mercu. Bangunan ukur dilengkapi dengan papan duga yang dipasang di hulu bangunan ukur. Papan duga ini berfugsi mengukur tinggi air di atas mercu. Dengan demikian, pengukuran debit menggunakan bangunan ukur dapat dilakukan dengan pembacaan tingi air menggunakan papan duga (Ginanjar \& Hariati, 2015). Berdasarkan hasil pengamatan menunjukkan bahwa kondisi aliran di udik bangunan ukur pada tinggi air di papan duga $1,7 \mathrm{~cm}-2,1 \mathrm{~cm}$ adalah seragam sehingga pembacaan tinggi air sangat akurat. Begitu pula kondisi aliran pada bangunan ukur debit terjadi kontraksi penuh dan aerasi sempurna. Dengan demikian dapat dikatakan bahwa bangunan ukur berfungsi dengan baik. 
4. Bak volumetrik berfungsi untuk mengukur debit aktual, dimana pengukuran debit ini dilakukan dengan menghitung volume air yang ditampung per satuan waktu. Pada umumnya satuan yang digunakan adalah liter/detik atau $\mathrm{m}^{3} /$ detik. Bak volumetrik ini berfungsi dengan baik dan tidak terjadi kebocoran serta pengukuran volume dapat dilakukan dengan baik.

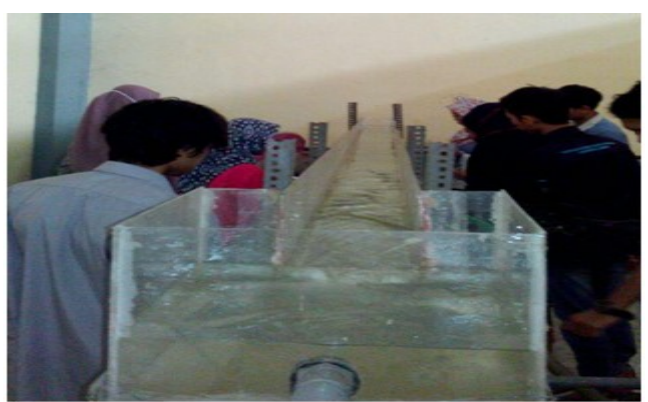

Gambar 8. Uji fungsi prototipe saluran irigasi

\section{Uji Kinerja}

Pengukuran Volume Aktual

Uji kinerja pada bak volumetrik dilakukan dengan pengukuran debit aktual. Pengukuran debit aktual dilakukan dengan cara menghitung volume air yang tertampung dan mencatat waktu yang diperlukan selama menampung air tersebut. Bak volumetrik dilengkapi dengan pembacaan tinggi air yang berfungi untuk mengkonversi tinggi air menjadi volume. Oleh karena itu, volume aktual pada bak volumetrik ini harus dikalibrasi terlebih dahulu dengan gelas ukur. Volume air dari gelas ukur dipindakan ke bak volumetrik, kemudian dibaca tinggi air pada skala pembacaan yang terpasang pada bak volumetrik. Pembacaan data tinggi air pada bak volumetrik dilakukan dengan 2 kali ulangan. Skala pembacaan dilengkapi dengan selang bening yang terhubung dengan air di dalam bak volumetrik. Air di dalam selang akan naik seiring dengan penambahan volume air di dalam bak volumetrik. Dengan demikian, pembacaan ketinggian air menggunakan selang meningkatkan akurasi pembacaan tinggi air. Hasil kalibrasi volume dapat dilihat pada Tabel 2 dan Gambar 9.
Tabel 2. Pengukuran tinggi air dan volume bak penampung

\begin{tabular}{ccc}
\hline $\begin{array}{c}\text { Volume } \\
\text { gelas ukur } \\
\text { (liter) }\end{array}$ & \multicolumn{2}{c}{$\begin{array}{c}\text { Tinggi air pada bak } \\
\text { volumetrik }(\mathrm{cm})\end{array}$} \\
\hline 0 & 0 & 0 \\
1 & 1 & 0,9 \\
2 & 1,9 & 1,8 \\
3 & 2,8 & 2,9 \\
4 & 3,7 & 3,6 \\
5 & 4,5 & 4,4 \\
6 & 5,4 & 5,3 \\
7 & 6,3 & 6,2 \\
8 & 7 & 7,1 \\
\hline
\end{tabular}

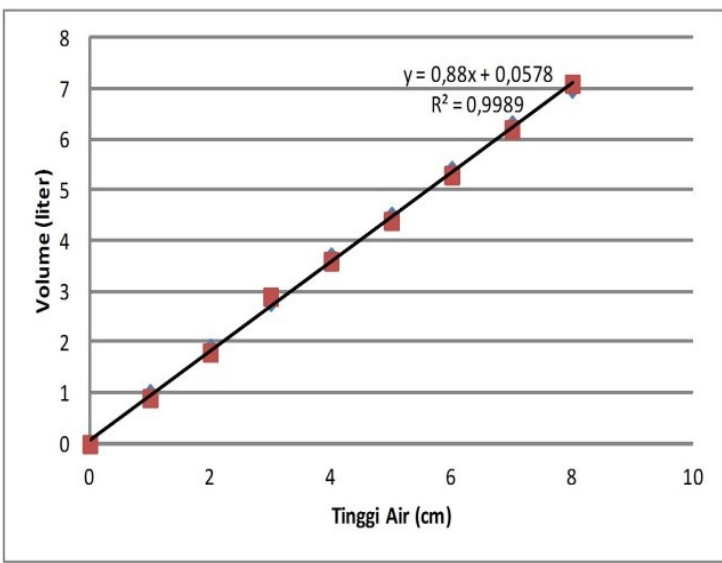

Gambar 9. Hubungan tinggi air pada bak penampung dengan volume terukur

Gambar 9 menunjukkan bahwa hubungan antara tinggi air dengan volume terukur menghasilkan persamaan 7 dengan $\mathrm{R}^{2}=0,999$. Hal ini menunjukkan bahwa pengukuran tinggi air pada bak volumetrik dapat digunakan untuk menghitung volume air tertampung dengan sangat baik.

$\mathrm{Y}=0,88 \mathrm{x}+0,0578$

Dimana Y adalah volume terukur (liter), $\mathrm{X}$ adalah tinggi air pada bak volumetrik $(\mathrm{cm})$. 
Tabel 3. Perhitungan debit aktual pada bak volumetrik

\begin{tabular}{cccccc}
\hline \multirow{2}{*}{ No } & \multirow{2}{*}{$\begin{array}{c}\text { Tinggi air } \\
(\mathrm{cm})\end{array}$} & $\begin{array}{c}\text { Waktu } \\
(\text { detik })\end{array}$ & $\begin{array}{c}\text { Volume } \\
(\text { Liter })\end{array}$ & \multicolumn{2}{c}{$\begin{array}{c}\text { Debit } \\
\text { (liter/detik) }\end{array}$} \\
\hline \multirow{2}{*}{ I } & 1 & 3,8 & 0,938 & 0,247 & 0,275 \\
& 1 & 3,1 & 0,938 & 0,303 & \\
II & 1 & 3,1 & 0,938 & 0,303 & 0,289 \\
& 1 & 3,4 & 0,938 & 0,276 & \\
III & 1 & 4,3 & 0,938 & 0,218 & 0,226 \\
& 1 & 4 & 0,938 & 0,235 & \\
IV & 1 & 4,2 & 0,938 & 0,223 & 0,218 \\
& 1 & 4,4 & 0,938 & 0,213 & \\
\hline
\end{tabular}

Perhitungan Debit Aktual dan Debit Teoritis

Perhitungan debit aliran air pada prototipe saluran irigasi ini dilakukan dengan dua cara yaitu pengukuran debit secara langsung dan tidak langsung. Pengukuran debit secara langsung menggunakan bak volumetrik dengan pembacaan tinggi muka air dan waktu. Pembacaan waktu dilakukan selama pengukuran tinggi air, sehingga dihasilkan data tinggi air per satuan waktu. Data tinggi muka air tersebut digunakan untuk menghitung volume aktual dengan persamaan 7. Dengan demikian debit aktual dapat dihitung dalam satuan volume per waktu menggunakan Persamaan 1. Sementara itu, pengukuran debit secara tidak langsung menggunakan prototipe bangunan ukur segi empat. Pengukuran debit dilakukan dengan pembacaan tinggi air pada papan duga. Perhitungan debit dengan bangunan ukur segi empat ini menggunakan persamaan 2 dan persamaan 5. Hasil perhitungan debit aktual dapat dilihat pada Tabel 3 .

Tabel 3 menunjukkan bahwa pengukuran volume air di bak volumetrik dilakukan 8 kali pengulangan dengan waktu pengamatan yang berbeda dan tinggi air ditetapkan $1 \mathrm{~cm}$. Perbedaan waktu pengamatan ini menghasilkan debit aktual yang berbeda pula. Sementara itu, pengukuran tinggi air pada papan duga dilakukan pada waktu dan pengulangan yang sama dengan pengukuran volume aktual. Data tinggi air pada papan duga ini digunakan untuk menghitung debit teoritis seperti tampak pada Tabel 4 dan Tabel 5 . Hal ini juga sejalan dengan hasil penelitian yang dilakukan oleh Ginanjar dan Hariati (2015) bahwa waktu pengamatan tinggi air akan berpengaruh terhadap debit aktual di bak volumetrik.

Tabel 4. Perhitungan debit dengan persamaan Kinsvater-Carter

\begin{tabular}{ccccc}
\hline No & $\begin{array}{c}\text { Tinggi air } \\
(\mathrm{cm})\end{array}$ & $\mathrm{Cd}$ & \multicolumn{2}{c}{ Kinsvater-Carter (liter/detik) } \\
\cline { 4 - 5 } I & 2,1 & 0,59 & 0,318 & Rata rata \\
\hline \multirow{2}{*}{ II } & 2,1 & 0,59 & 0,318 & 0,318 \\
& 2 & 0,59 & 0,296 & 0,296 \\
III & 2 & 0,59 & 0,296 & 0,252 \\
& 1,8 & 0,59 & 0,252 & 0,232 \\
IV & 1,8 & 0,59 & 0,252 & \\
& 1,7 & 0,59 & 0,232 & \\
\end{tabular}


Tabel 5. Perhitungan debit dengan persamaan Umum

\begin{tabular}{ccccc}
\hline No & $\begin{array}{c}\text { Tinggi air } \\
(\mathrm{cm})\end{array}$ & $\mathrm{Cd}$ & \multicolumn{2}{c}{ Pers. Umum (liter/detik) } \\
\cline { 4 - 5 } I & 2,1 & 0,59 & 0,281 & Rata-rata \\
& 2,1 & 0,59 & 0,281 & 0,281 \\
II & 2 & 0,59 & 0,261 & 0,261 \\
& 2 & 0,59 & 0,261 & \\
III & 1,8 & 0,59 & 0,223 & 0,223 \\
& 1,8 & 0,59 & 0,223 & 0,205 \\
IV & 17 & 0,59 & 0,205 & \\
& 1,7 & 0,59 & 0,205 & \\
\hline
\end{tabular}

Tabel 4 dan 5 menunjukkan bahwa hasil perhitungan debit teoritis menggunakan persamaan Kinsvater-carter dan persamaan umum berbeda dengan debit aktual pada masing-masing pengulangan. Debit aktual ini digunakan sebagai kontrol terhadap debit teoritis. Oleh karena itu, adanya perbedaan antara debit aktual dengan debit teoritis perlu dilakukan perhitungan koefisien kalibrasi menggunakan persamaan 6. Hal ini juga sejalan pendapat Suhardi (2019) yang menyatakan bahwa debit hasil perhitungan dengan persamaan Kinsvater-carter dan persamaan umum berbeda dengan debit aktual. Hasil perhitungan koefisien kalibrasi dapat dilihat pada Tabel 6 berikut ini.
Tabel 6 menunjukkan bahwa koefisien kalibrasi rata-rata persamaan Kinsvatercarter terhadap debit aktual adalah 0,868. Sementara itu, koefisien kalibrasi rata-rata antara debit teori berdasarkan persamaan umum terhadap debit aktual adalah 0,983 Hal ini menunjukkan bahwa perhitungan debit aktual dan debit teoritis menggunakan persamaan Kinsvater-carter dan persamaan umum sangat akurat. Hal yang sama dikemukakan oleh Suhardi (2019) bahwa hasil percobaan aplikasi persamaan Kinsvater-carter dan persamaan umum pada bangunan ukur ambang tajam segi empat yang terpasang pada hydraulic bench sangat akurat dengan koefisien kalibrasi 0,89 dan 0,94 .

Tabel 6. Koefisien kalibrasi debit

\begin{tabular}{cccccc}
\hline \multirow{2}{*}{ No } & \multicolumn{2}{c}{ Debit teoritis dan aktual (lt/det) } & \multicolumn{2}{c}{ Koefisien kalibrasi } \\
\cline { 2 - 6 } & Kinsvater - carter & Umum & Aktual & Kinsvater carter & Umum \\
\hline \multirow{2}{*}{ I } & 0,318 & 0,281 & 0,247 & 0,776 & 0,878 \\
& 0,318 & 0,281 & 0,303 & 0,951 & 1,076 \\
\multirow{2}{*}{ II } & 0,296 & 0,261 & 0,303 & 1,023 & 1,158 \\
& 0,296 & 0,261 & 0,276 & 0,933 & 1,056 \\
\multirow{2}{*}{ III } & 0,252 & 0,223 & 0,218 & 0,864 & 0,978 \\
& 0,252 & 0,223 & 0,235 & 0,929 & 1,051 \\
IV & 0,232 & 0,205 & 0,223 & 0,689 & 0,780 \\
& 0,232 & 0,205 & 0,213 & 0,779 & 0,882 \\
\hline \multicolumn{7}{c}{ Rata-rata } \\
\hline
\end{tabular}


Tabel 7. Kinerja model JST untuk memprediksi debit bangunan ukur dengan persamaan Kinsvatercarter dan persamaan umum

\begin{tabular}{cccc}
\hline & \multicolumn{2}{c}{ MSE } & \multicolumn{2}{c}{ MSE } \\
& Persamaan Kinsvater-carter & \multicolumn{2}{c}{ Persamaan Umum } \\
\hline Train & 0,0001 & Train & $1,57 \mathrm{e}-18$ \\
Valid & 0,0011 & Valid & $1,63 \mathrm{e}-04$ \\
Test & 0,0044 & Test & 0,0002 \\
\hline
\end{tabular}

Tabel 8. Debit bangunan ukur ambang tajam segi empat menggunakan persamaan teoritis dan model JST

\begin{tabular}{ccccc}
\hline \multirow{2}{*}{ No } & \multicolumn{2}{c}{ Debit teoritis (lt/det) } & \multicolumn{2}{c}{ Debit model JST (lt/det) } \\
\cline { 2 - 5 } & Kinsvater- carter & Umum & Kinsvater- carter & Umum \\
\hline \multirow{2}{*}{ I } & 0,318 & 0,281 & 0,412 & 0,274 \\
& 0,318 & 0,281 & 0,307 & 0,261 \\
II & 0,296 & 0,261 & 0,307 & 0,261 \\
& 0,296 & 0,261 & 0,283 & 0,261 \\
III & 0,252 & 0,223 & 0,246 & 0,215 \\
& 0,252 & 0,223 & 0,254 & 0,223 \\
IV & 0,232 & 0,205 & 0,387 & 0,343 \\
& 0,232 & 0,205 & 0,411 & 0,339 \\
\hline
\end{tabular}

\section{Validasi Perhitungan Debit Teoritis Menggunakan Jaringan Saraf Tiruan (JST)}

Debit teoritis menggunakan persamaan Kinsvater-carter dan persamaan umum divalidasi dengan model Jaringan Saraf Tiruan (JST). Debit aktual sebagai data input sementara debit teoritis sebagai target. Hasil model menunjukkan bahwa kinerja model sangat akurat pada tahap training, validation dan testing dimana nilai Mean Square Error (MSE) dari target sangat kecil seperti tampak pada Tabel 7 sementara debit bangunan ukur hasil pemodelan JST dapat dilihat pada Tabel 8.
Tabel 8 menunjukkan bahwa debit bangunan ukur menggunaan persamaan Kinsvater-carter dan persamaan Umum relatif sama dengan debit hasil model. Hal ini menunjukkan bahwa kinerja pengukuran debit prototipe bangunan ukur ambang tajam segi empat menggunakan persamaan Kinsvater-carter dan persamaan Umum sangat akurat. Tahap selanjutnya adalah memvalidasi koefisien kalibrasi bedasarkan data debit teoritis dan aktual dengan debit model JST dan debit aktual. Tujuan dari validasi ini adalah mengetahui tingkat akurasi koefisien kalibrasi persamaan Kinsvater-carter dan Persamaaan Umum seperti tampak pada Tabel 9.

Tabel 9. Koefisien kalibrasi debit bangunan ukur ambang tajam segi empat model JST

\begin{tabular}{|c|c|c|c|c|c|}
\hline \multirow{2}{*}{ No } & \multicolumn{2}{|c|}{ Debit model JST (lt/det) } & \multirow{2}{*}{$\begin{array}{c}\text { Debit aktual } \\
\text { (lt/det) }\end{array}$} & \multicolumn{2}{|c|}{ Koef. Kalibrasi (K) } \\
\hline & Kinsvater - carter & Umum & & Kinsvater - carter & Umum \\
\hline \multirow{2}{*}{ I } & 0,412 & 0,274 & 0,247 & 0,599 & 0,902 \\
\hline & 0,307 & 0,261 & 0,303 & 0,986 & 1,158 \\
\hline \multirow{2}{*}{ II } & 0,307 & 0,261 & 0,303 & 0,986 & 1,158 \\
\hline & 0,283 & 0,261 & 0,276 & 0,974 & 1,056 \\
\hline \multirow{2}{*}{ III } & 0,246 & 0,215 & 0,218 & 0,887 & 1,013 \\
\hline & 0,254 & 0,223 & 0,235 & 0,924 & 1,051 \\
\hline \multirow{2}{*}{ IV } & 0,387 & 0,343 & 0,223 & 0,693 & 0,780 \\
\hline & 0,411 & 0,339 & 0,213 & 0,692 & 0,839 \\
\hline \multicolumn{4}{|c|}{ Rata-rata } & 0,843 & 0,995 \\
\hline
\end{tabular}


Tabel 9 menunjukkan bahwa nilai rata-rata koefisien kalibrasi berdasarkan debit model JST dan rata-rata koefisien kalibrasi berdasarkan debit teoritis relatif sama yaitu 0,868 dan 0,843 pada persamaan Kinsvater-carter, sementara persamaaan Umum 0,983 dan 0,995. Hal ini menunjukkan bahwa hasil kalibrasi bangunan ukur ambang tajam segi empat menggunakan persamaan Kinsvater-carter dan persamaan Umum sangat akurat.

\section{KESIMPULAN}

Berdasarkan hasil percobaan menggunakan prototipe saluran irigasi skala laboratorium ini dapat dikemukakan bahwa kolam olak berfungsi dengan baik sehingga aliran air pada saluran pembawa menjadi stabil dan tidak berpotensi terjadi gerusan pada dinding dan dasar saluran. Begitu pula dengan saluran pembawa tidak terjadi kebocoran sehingga fungsi saluran pembawa untuk mengalirkan air cukup efisien. Kinerja bangunan ukur ambang tajam segi empat sangat baik, ditunjukkan dari nilai koefisien kalibrasi persamaan Kinsvater-carter terhadap debit aktual 0,868 dan koefisien kalibrasi persamaan Umum terhadap debit aktual 0,983. Dengan demikian dapat dikemukakan pula bahwa persamaan Kinsvater-carter dan persamaan Umum dapat diimplementasikan untuk pengukuran debit dan kalibrasi bangunan ukur ambang tajam segi empat di saluran irigasi.

\section{UCAPAN TERIMA KASIH}

Terimakasih kepada Ketua Laboratorium Teknik Pengendalian dan Konservasi Lingkungan (TPKL) Jurusan Teknik Pertanian Fakultas Teknologi Pertanian yang telah mendukung penelitian rancang bangun prototipe saluran irigasi skala laboratorium ini.

\section{DAFTAR REFERENSI}

Al Shaikhli, H. I., \& Kadhim, K. N. (2018). Development an Equations For Flow Over Weirs Using MNLR and CFD Simulation Approaches. International Journal of Civil Engineering and Technology, 9(3), 70-79.

Anggrahini. (2005). Hidrolika Saluran Terbuka. (Devita, Ed.). Surabaya: Srikandi.

Badan Standardisasi Nasional. (2015). Pengukuran Debit pada Saluran Terbuka Menggunakan Bangunan Ukur Tipe Pelimpah Atas. BSNI. Jakarta. Diakses dari www.bsn.go.id.

Bagus, A.M., Edijanto, \& Soesanto, S.R. (2018). Irigasi dan Bangunan Air. Modul kuliah Irigasi dan Bangunan Air (RC18-4603). Departemen Teknik Sipil FTSLK-ITS. Surabaya. Diakses dari

https://www.researchgate.net/profile/ Mohamad_Ansori/publication/32333 5382_Irigasi_dan_Bangunan_air/link s/5afa8747a6fdccacab16aeb9/Irigasidan-Bangunan-Air.pdf.

Direktorat Jenderal Pengairan, \& Umum, D. P.D. (1986). Kriteria Perencanaan Bagian Parameter Bangunan KP - 06. Bandung: CV. Galang Persada.

Direktorat Jenderal Sumber Daya Air. (2013). Standar Perencanaan Irigasi Kriteria Perencanaan Saluran KP-03. Jakarta.

Edijantno, Lasminto, U., Andiek, M., Rartri, Y., \& Sumirman, E. (2019). Uji Kinerja Alat Ukur Ambang Tajam Berpenampang Majemuk. Prosiding Pertemuan Ilmiah Tahunan HATHI, $1-11$.

Elsafi, S.H. (2014). Artificial Neural Networks (ANNS) For Flood 
Forecasting At Dongola Station In The River Nile, Sudan. Alexandria Engineering Journal, 53, 655-662. doi:10.1016/j.aej.2014.06.010.

Ginanjar, B., \& Hariati, F. (2015). Analisis Koefisien Debit Model Alat Ukur Celah Segiempat di Laboratorium Hidrolika Teknik Sipil Universitas Ibn Khaldun Bogor. Jurnal Rekayasa Sipil, 4(2), 18-24.

Hidayah, S., \& Dermawan, V. (2015). Uji Proporsionalitas Debit Bangunan Bagi Tipe Numbak. Jurnal Irigasi, 10(2), 69-82.

Pudyono. (2010). Pengaruh Pemasangan Bangunan Peninggi Muka Air (Subweir) Terhadap Gerusan Yang Terjadi di Hilir Bendung. Jurnal Rekayasa Sipil, 4(2), 99-110.

Sisiwoyo, H., Wahyudi, S.I., \& Soedarsono. (2017). Analisis Efisiensi Jaringan Saluran Irigasi. Prosiding Seminar Nasional Inovasi dalam Pengembangan Smart City, 1(1), 237-251.

Suhardi. (2015). Rekayasa Dan Uji Kinerja Prototipe Destilator Skala Laboratorium. Jurnal Agroteknologi, 09(02).

Suhardi. (2019). Aplikasi Persamaan Rehbock, Kinsvater - Carter, dan Persamaan Umum Pada Bangunan Ukur Segi Empat Skala Laboratorium.
Jurnal Pendidikan Fisika Dan

Teknologi, 5(2), 1-9. doi:10.29303/jpft.v5i2.1383.

Sumirman, E., \& Lasminto, U. (2013). Studi Perbandingan Aliran Alat Ukur Debit Ambang Tipis Penampang Segi Tiga Dengan Penampang. Prosiding Seminar Nasional Aplikasi Teknologi Prasarana Wilayah (ATPW), 1-18.

Susetyaningsih, A. dan S. Permana. (2016). Pengaruh Sedimentasi Terhadap Penyaluran Debit Pada Daerah Irigasi Cimanuk. Jurnal Konstruksi Sekolah Tinggi Teknologi Garut, 14(1),149153.

Ulfiana, D. (2018). Studi Efektivitas Pola Pemasangan Baffled Block pada Peredam Energi dalam Mereduksi Energi Aliran. Institut Teknologi Sepuluh Nopember.

Waspodo. (2017). Analisa Head Loss Sistem Jaringan Pipa pada Sambungan Pipa Kombinasi Diameter Berbeda. Jurnal Suara Teknik Fakultas Teknik, $8(1), 1-12$.

Yusuf, A., Sugandi, W. K., -, Z., \& Tua, C. F.G. (2017). Rancang Bangun Mesin Pengolah Ganyong Multi Fungsi. Jurnal Ilmiah Rekayasa Pertanian dan Biosistem, 5(2), 462-471. doi: 10.29303/jrpb.v5i2.61. 